\title{
Viral Encephalitis
}

National Cancer Institute

\section{Source}

National Cancer Institute. Viral Encephalitis. NCI Thesaurus. Code C35302.

Encephalitis resulting from viral infection. 